\title{
John Fletcher's Collaborator on The Noble Gentleman
}

\section{Darren Freebury-Jones*}

\begin{abstract}
Although John Fletcher is recognized as one of the most influential dramatists of the early modern period, many of the theories concerning the divisions of authorship in his collaborative plays continue to present insoluble difficulties. For instance, according to the soundly based chronology developed by Martin Wiggins, many plays attributed in part to Francis Beaumont appear to have been written after Beaumont had ceased writing (c. 1613), or even after he died in 1616. A prime example would be The Noble Gentleman (1626), which E. H. C. Oliphant and Cyrus Hoy attributed in part to Beaumont. Modern scholarship holds that this was Fletcher's last play and that it was completed by another hand after Fletcher died in 1625 . This article offers the most comprehensive analysis yet undertaken of the stylistic qualities of the "non-Fletcher" portions in this play in relation to dramatists writing for the King's Men at the time, thereby opening up several new lines of enquiry for co-authored plays of the period. Seeking to broaden our understanding of the collaborative practices in plays produced by that company in or around 1626, through a combination of literary-historical and quantitative analysis, the article puts forth a new candidate for Fletcher's posthumous collaborator: John Ford.
\end{abstract}

Keywords: John Fletcher, Francis Beaumont, John Ford, prosody, linguistic habits, n-grams

The Noble Gentleman (1626) was licensed for performance by Sir Henry Herbert on 3 February 1626 for performance at the Blackfriars Theatre by the King's Men playing company. ${ }^{1}$ This was 5 months after John Fletcher's death. The play was included in both the first (1647) and second (1679) Beaumont and Fletcher folios and appears to have been printed from authorial copy. The Noble Gentleman is a farcical comedy in which Monsieur Mount-Marine has run out of money and decides to leave the court in order to live in the country. His wife desperately wants to stay living in the town and therefore

* Author's address: Darren Freebury-Jones, The Shakespeare Birthplace Trust, The Shakespeare Centre, Henley Street, Stratford-upon-Avon, CV37 6QW. E-mail: darren_f.j@hotmail.co.uk.

1 I follow the chronology of Martin Wiggins and Catherine Richardson's British Drama 1533-1642: A Catalogue throughout this article. 
concocts a plan to convince her husband that the King of France has offered him a dukedom. Meanwhile, Chatillon is equally deluded into believing that a lady who has denied his hand in marriage has been imprisoned by the King as a rival claimant to the throne. The play concludes with Marine being told that he can remain a duke so long as he does not inform anyone of his title, and Chatillon being told that the lady he loves has been released from prison.

The play has generated scholarly discussion in terms of authorship and chronology. Henry William Weber argued that the play was never acted during Fletcher's lifetime and that, having been "left imperfect" by him, "some of his friends finished it" (qtd in Dyce 1846: 110). This was a reasonable theory and worth pursuing, but it was ignored or dismissed by subsequent scholars. For instance, E. H. C. Oliphant conjectured that Francis Beaumont had a hand in the play in 1927 (183-200), as did Robert F. Wilson in 1968. Both scholars therefore argued for an early date of composition. In his wide-ranging study of plays in the Fletcher and Beaumont canons, Cyrus Hoy conjectured that Fletcher had revised an early work of Beaumont's sole authorship, and argued that Beaumont's hand could be most clearly detected in 1.4, 2.2, 3.1, 3.3-4, and 4.3-5. He considered the rest of the play to be of mixed authorship. Through a combination of literary-historical and statistical analysis, it is my aim here to provide the most comprehensive examination ever undertaken of the stylistic qualities of the "non-Fletcher" portions in this play, and to establish a firm basis for its authorial provenance.

It is therefore necessary that this essay avail itself of the terminology of early modern authorship attribution studies. Attribution studies aim to distinguish the author or authors of a play by identifying stylistic features that discriminate one writer from another. This has largely been attempted by scholars since the nineteenth century through close study of verse habits; authorial preferences for particular word forms; and parallels of thought, language, and overall dramaturgy between authors' accepted works and disputed plays. There are a large number of unresolved problems in this subject area: many plays of the period were published anonymously, or were attributed erroneously on title pages or in play lists. It is well-established that many plays in the Beaumont and Fletcher folios contain the hands of writers who were not advertised by the publishers, such as Nathan Field and Philip Massinger.

Studies of texts attributed to Fletcher and Beaumont have led to major breakthroughs in methodologies for discriminating authorial styles in the canon of early modern drama as a whole. In 1874, F. G. Fleay pointed out that the number of so-called double, or "feminine" endings (pentameter lines concluding in extra syllables), were more numerous in Fletcher's works than those of his contemporaries and that his range was much higher than Philip 
Massinger's. He also noted the occurrence of "frequent pauses at the end" of Fletcher's lines and stated that the "union of 'the stopped line' with the double ending is peculiar to Fletcher" (53). Whereas Fletcher "used the stopped line, usually", Massinger tended to end "his lines with words that cannot be grammatically separated from the next line; articles, prepositions, auxiliaries” (57), which helped Fleay to distinguish the dramatists' shares in co-authored plays like The Little French Lawyer (1620). Fleay also pointed out the "abundance of 'tri-syllabic feet"' in Fletcher's works (53). Oliphant's analysis of Fletcher's verse style in 1927 validated many of Fleay's observations, especially the dramatist's habit of employing double or triple endings, often "by means of some conventional and wholly unnecessary end word (such as 'still' or 'else' or 'too')" (33). Oliphant also drew attention to the fact that Fletcher avoided run-on lines and rhyme (36), concluding that his style was easily distinguishable from Beaumont's frequent use of run-on lines, single endings, and his general avoidance of the "emphatic extra syllable" (50). Nevertheless, Oliphant conceded that Beaumont "attained no stability of style" during "his brief career" (80). Fletcher's predilection for extra-metrical verse lines was observed by Ants Oras in 1953. Oras demonstrated that there were "unmistakeable differences" between portions assigned to Fletcher and his co-author (201), Shakespeare whose portions have a much lower incidence of feminine endings formed by monosyllables - in All is True (1612) and The Two Noble Kinsmen (1613).

More recently, Marina Tarlinskaja has provided a thorough examination of Fletcher's versification characteristics, pointing out that Fletcher and Beaumont's portions of The Maid's Tragedy (1611) are distinguished by the "total number of end-stopped lines: 77.6 percent in Fletcher's portion" and "only 66.4 in Beaumont's" (2014: 203), while Massinger's rate of run-on lines in The False One (1620) is "almost five times more" frequent than in Fletcher's portions of that play (220). We can see therefore that verse studies provide powerful tools for discriminating dramatists and that a combination of qualitative and quantitative prosodic analyses offers profound insights into the distinctive features of Fletcher and his co-authors' styles.

Studies of linguistic preferences have also enhanced our knowledge of Fletcher and his collaborators. For example, in 1901 Ashley H. Thorndike pointed out that Fletcher frequently employed the contracted form "em" rather than "them" (24), while W. W. Greg drew attention to Fletcher's propensity for the pronominal form "ye", rather than "you" (1905: 4). Similarly, scholars like W. E. Farnham were able to discriminate Fletcher's hand through his use of contractions like "i'th" and "o'th" (1916: 326-358). Between 1956 and 1962, Cyrus Hoy built upon these findings and provided the most comprehensive study of Fletcher's canon in the history of the field. Hoy's delineation 
of authorial contributions to co-authored Fletcher plays was based largely on aforementioned synonym preferences and favoured contractions. However, the creation of large electronic corpora enables researchers to generate results in a fraction of the time that older scholars like Hoy would take. For instance, Pervez Rizvi's publicly accessible electronic corpus of 527 plays dated between 1552 and 1657, titled Collocations and $\mathrm{N}$-grams, ${ }^{2}$ automatically tags all words in early modern texts, enabling users to ascertain the ratios for synonym preferences and contractions.

As well as examining single words, scholars like Fleay, Oliphant, and Hoy studied verbal parallelisms in order to identify Fletcher's idiosyncratic thought processes and formulaic utterances. Ian Lancashire notes that word "chunks", or phrases, "are the linguistic units we work with most: they fit into working memory and resemble what we store associatively" (2010: 180), while Brian Vickers explains that

Where earlier linguistic theories held that users of natural language selected single words to be placed within a syntactical and semantic structure, it now became clear that we also use groups of words, partly as a labour-saving device, partly as a function of memory. Such verbal economy is particularly prevalent in the drama written for the public theatres, where constraints of time demand speedy composition, characters fall into a set of roles with attendant speech patterns, and the verse line easily admits ready-made phrases. It is hardly surprising that many dramatists frequently repeat themselves (2014: 111).

The results in Rizvi's Collocations and N-grams are fully automated and enable scholars to check for every contiguous word sequence shared between plays. Searches of the lemmatized texts allow a wider range of phrasal matches to be discovered than by searches using original spelling or the unlemmatized forms of words. In corpus linguistics, the root form of each word (i. e. the lemma) is counted, so that "kind hearts" is matched with "kind-hearted", to offer one example. Without the aid of modern electronic corpora, older scholars could never claim that an utterance they associated with an authorial candidate was unique or commonplace, but we can now ascertain exactly how many times a phrase appears in extant drama of the period, and in which plays. As we shall see, there are several ways of examining the data in Rizvi's Collocations and $\mathrm{N}$-grams, which provides a powerful tool for distinguishing dramatists.

2 Available online at http://shakespearestext.com/can/. 
In 1932, Muriel St. Clare Byrne demonstrated that verbal parallelisms can offer valuable evidence in authorship attribution studies, provided scholars adhere to the following criteria: parallels may be due to plagiarism, either conscious, unconscious, or coincidental, rather than common authorship; mere verbal parallelism is of little value in comparison to parallelism of thought coupled with some verbal parallelism; and mere accumulation of parallels is of no significance (24). These criteria still hold true, despite changes in the philological basis of attribution studies. Scholars operating in the pre-electronic age were able to identify dramatists' hands through the traditional discipline of reading plays closely and highlighting instances of authorial self-repetition. Such approaches, paying close attention to the verbal fabric of plays, remain essential in authorship attribution. There have been considerable advances in statistical analyses of early modern plays, with the inclusion or exclusion of texts in recent and forthcoming editions of the works of writers like Thomas Kyd, Thomas Nashe, Shakespeare, John Marston, John Ford, and Aphra Behn dependent, at least in part, on large-scale computational attribution work. The studies underpinning these editions tend to rely on online databases such as Literature Online (LION), ${ }^{3}$ Early English Books Online (EEBO), ${ }^{4}$ and Collocations and $N$-grams in order to uncover minute details of poetic texts and therefore establish homogeneity between dubious works and the corpora of authorial candidates. The most convincing contributions to the field anchor such data-driven approaches, which offer more precise methodologies for work conducted by attributionists over the centuries, in an understanding of theatrical and historical context, as well as sensitive readings of dramatic works. $^{5}$

Many of Hoy's theories continue to present insoluble difficulties. In the case of The Noble Gentleman, the play's "decidedly un-Fletcherian" linguistic pattern suggested to him that Beaumont wrote the original play in 1605 or 1606 (1958: 94-95). However, Fredson Bowers has pointed out that "Hoy does not mention that the play could as easily have been a collaboration from the start" or that "it could have been completed by another hand after Fletcher's death". Although Bowers was not willing to "say who had been the other author" (1976: 117),

\footnotetext{
3 Available online at http://lion.chadwyck.co.uk.

4 Available online at http://eebo.chadwyck.com/home.

5 For a survey of the history and current state of the field of authorship attribution studies, and recent applications of statistical methods to early modern texts, see my essay: "When a man hath a familiar style': An Introduction to Authorship Studies in Early Modern Drama and Literature" (Freebury-Jones 2020).
} 
he suggested that Hoy "has slipped in his interpretation of the statistics", for the "linguistic habits in the text" that Hoy examined are not "distinctively Beaumont's", who was anyway "eclectic in his preferences" (118). Recently, I reinvestigated the layers of collaboration and revision in Fletcher's corpus and found that many plays that Hoy ascribed in part to Beaumont were composed after that dramatist had ceased writing (c. 1613), or even after he died in 1616 (Freebury-Jones, forthcoming). For instance, while Hoy attributed 14 plays in part or wholly to Beaumont, my researches have led me to assign 8 plays to Fletcher and Beaumont as co-authored works: The Woman Hater (1606); Cupid's Revenge (1607); Philaster, or Love Lies a-Bleeding (1609); The Coxcomb (1609); The Scornful Lady (1610); A King and No King (1611); The Maid's Tragedy; and The Captain (1612). As Martin Wiggins puts it: "Differentiating the 'shadow Beaumont' from the real one would be a useful task for future authorship research" (2015: 518). Following up Wiggins's suggestion, I discovered that many play portions that Hoy gave to Beaumont were reliably attributable to playwrights like Nathan Field.

Wiggins agrees with scholars like Weber that "In all likelihood, Fletcher died leaving" The Noble Gentleman "unfinished, like The Fair Maid of the Inn [...] but in a later state of preparation. If so, there are obvious reasons for the disruption of Fletcher's usual style: the play would have been completed by another hand, probably concurrently with the work on The Fair Maid undertaken by Webster, Massinger, and Ford" (2017: 166). Wiggins provides a cogent survey of arguments that the play belongs to an earlier stage of Fletcher's writing career and concludes that the "date rests on the single undeniable piece of external evidence: Herbert's licence. Herbert usually mentioned when he was relicensing an old play [...] therefore, prima facie, the play was new when licensed" (166). I concur with the view that another dramatist completed the play and in this article I examine the fundamental principles of dramatic authorial style - namely prosody, linguistic habits, and verbal repetitions - in comparison to other playwrights working for the King's Men at the time that the play was completed.

As we have seen, the theory that Beaumont contributed to The Noble Gentleman is unsustainable in light of revised chronology. We must instead look to a dramatist who was writing for the King's Men and was free to work on the play in the latter half of 1625. Firstly, it is necessary to ask ourselves: what is at stake in attributing parts of this play? I propose that ascertaining the authorship of The Noble Gentleman will offer a major contribution to our understanding of the King's Men repertoire and the ways in which plays of the period were composed, and will enhance knowledge on the impact of revision, or, in this case, posthumous collaboration, on authorial stylistic habits. 
Moreover, if we can establish the identity of Fletcher's collaborator, we can deepen our understanding of that particular writer's stylistic range, augment his dramatic canon, and situate this play in the context of his career as a King's Men playwright. This study therefore has the potential to open up several new lines of enquiry for co-authored plays of the period.

To begin with, I compared the linguistic profile that Hoy provided for portions he gave to Beaumont to all feasible candidate playwrights. Searching the spreadsheets for "1-grams", meaning single words, in Pervez Rizvi's corpus of 527 plays, I found that the "non-Fletcher" profile was not unlike John Webster's in that both playwrights scarcely use "has" (there is just 1 instance in the "non-Fletcher" portions), "does" (3 instances in the "non-Fletcher" portions), or "'em" (3 instances), but that Webster's characteristic contractions - like "for's", “for't", "in's", "in't", “o'th", "on't", "upon't", and "'s" - have lower rates of recurrence in The Noble Gentleman. Thomas Middleton satisfies the circumstantial requirements and, indeed, Wiggins suggests that the "possibility of contributions by Thomas Middleton might be worth investigating" (2017: 166). However, Hoy's findings for "hath", "doth", and the preference for "them" in The Noble Gentleman do not suggest Middleton's habits, for he appears to have overwhelmingly preferred "has", "does", and "'em". Wiggins notes that the "linguistic markers for Middleton, distinctive in his early work, tend to be weaker in his later writing" (166), yet the overall pattern in this play is poles apart. Other potential candidates for Fletcher's posthumous collaborator are Robert Davenport, Henry Shirley, and Richard Brome.

Davenport has been described as "one of the most obscure dramatists of the Caroline era" by David Kathman. The "first certain record of Davenport comes on 10 April 1624, when The Historye of Henry the First, Written by Damport was licensed for the King's Men by the master of the revels". That play, along with "another lost play, Henry the 2nd", was "entered in the Stationers' register in 1653". Kathman also notes that on "14 October 1624 another play of Davenport's, The City Night-Cap, was licensed for Lady Elizabeth's men at the Cockpit", while "Davenport's next known play, King John and Matilda, is a reworking of Chettle and Munday's Death of Robert Earl of Huntington". An additional play that has been attributed to Davenport, $A$ New Trick to Cheat the Devil (1626), shares an overwhelming preference for "hath" over "has" (76:1), "doth" over "does" (16:1), and "them" over "em" (43:0) with Fletcher's collaborator on The Noble Gentleman, but Davenport prefers "has" (36 instances as opposed to 29 "hath") in The City Nightcap (1624) and has an equal ratio of "doth" and "does" (3:3) in King John and Matilda (1628); all of his plays display a marked preference for "you" over "ye" and "them" over "em". 
Kathman observes that "Shirley's one surviving play, The Martyred Soldier, is a Christian martyr play set among the medieval Vandals and Goths", which was "licensed in 1622-1623 for Lady Elizabeth's Men at the Cockpit and then for Palsgrave's Men at the Fortune, but it was not entered in the Stationers' register until 15 February 1638 and was published that year". He elaborates that "Four plays were attributed to Shirley in a Stationers' register entry of 1653 but are now lost. These include 'The Duke of Guise' and 'Giraldo, the Constant Lover', about which nothing more is known; 'The Dumb Bawd of Venice', which was performed by the King's Men at court in 1628; and 'The Spanish Duke of Lerma', which was owned by the King's Men in 1641". The Martyred Soldier (1622) reveals an overwhelming propensity for "you" over "ye" (227:4) and "them" over "'em" (43:13), but Shirley's predilection for "has" over "hath" (30:11) and "does" over "doth" (7:4) does not fit the linguistic profile for The Noble Gentleman sample.

Brome's extant dramatic corpus is much larger than Davenport's or Shirley's. Martin Butler notes that "At some time during the 1620s Brome moved into theatre on his own account. In 1623 a now lost play, 'A Fault in Friendship', 'by Young Johnson, and Brome', was licensed for the Prince's Men, who were performing at the Curtain", but "Brome's writing career took off in 1629 , when he achieved two big successes with London's premier company, the King's Men: 'The Lovesick Maid, or, The Honour of Young Ladies' (licensed on 9 February) and 'The Northern Lass' (first acted on 29 July, published in 1632)". Brome's first known work for the King's Men was therefore written in 1629 , but he seems to have been writing for the stage from 1623 and is thus a feasible candidate for The Noble Gentleman. Nevertheless, all of Brome's plays display a marked preference for "has" and "does", while there is some vacillation in terms of "them" and "em". His linguistic profile, like Middleton and Shirley's, is quite unlike that found in The Noble Gentleman.

Although I tested Webster's linguistic profile, he is one of the least likely candidates mentioned above, given that he would have been working on The Fair Maid of the Inn (1626) at the time according to Wiggins's chronology, as the play's main co-author. Another writer working on that play - but whose contributions were much less extensive than Webster's - is John Ford, who also favoured "hath", "doth" (with the sole exception of The Lady's Trial, which contains 9 instances of "does" as opposed to 6 examples of "doth"), and "them" in each of his plays. I tested the "non-Fletcher" scenes in The Noble Gentleman against Brian Vickers's mean values for linguistic preferences in Ford's soleauthored plays (2017: 95). Vickers established these values by dividing the total figure for each marker by the number of unassisted Ford plays. I tabulate these markers below: 
Table 1. Linguistic Markers in "Beaumont" Portions of The Noble Gentleman and Ford Plays

\begin{tabular}{|l|l|l|}
\hline Marker & Ford & The Noble Gentleman Collaborator \\
\hline Ye & 11 & 9 \\
\hline You & 288 & 225 \\
\hline Hath & 40 & 17 \\
\hline Doth & 9 & 12 \\
\hline 'em & 10 & 3 \\
\hline Them & 23 & 15 \\
\hline i'th & 4 & 2 \\
\hline o'th & 1 & 1 \\
\hline has & 3 & 1 \\
\hline 's & 0.3 & 1 \\
\hline
\end{tabular}

To my eyes, there is a high degree of community between the figures found in portions attributed to Fletcher's collaborator on The Noble Gentleman, and the mean values for Ford's 8 unassisted plays.

We might also note the presence of a contraction that H. D. Sykes identified as characteristic of Ford (1924: 188): "d'ee" (often modernized as "d'ye"). However, the form, "d'ee", or "d'ye", is certainly not unique to Ford: it can be found in plays by all of our candidate dramatists with the exception of Shirley's sole extant drama. Nevertheless, we should note that the formulation from 3.4 of The Noble Gentleman, "D'ee mock me", co-occurs with 'Tis Pity She's a Whore (1631) and is comparable to "D'ee mock my parentage" and "Why d'ee mock my sorrows" from The Fair Maid of the Inn and The Spanish Gypsy (1623) respectively. The only other playwright in Rizvi's corpus who employs the bigram (two-word phrase), "d'ye mock", is James Shirley, who was not writing for the King's Men when The Noble Gentleman was composed. It is also worth noting that the exclamation "pew" occurs in the "non-Fletcher" portions of The Noble Gentleman. Ford, Middleton, and Brome employ this word according to Rizvi's database (Ford in Love's Sacrifice and The Lady's Trial; Middleton in The Puritan; and Brome in The Weeding of Covent Garden), whereas Davenport and Shirley do not. On the basis of overall linguistic preferences, Ford fits the profile better than the other King's Men candidate dramatists.

In 1960, Ants Oras studied "the phenomenon of pauses" and the "positions they appear in the verse, and in what ratios compared with other positions in the line" (1-2). He suggested that "less conscious pause patterns" could 
help to answer questions of authorship (2). Oras recorded patterns for several Elizabethan and Jacobean dramatists "formed by all the pauses indicated by internal punctuation", which he termed A-patterns, as well as patterns for "pauses shown by punctuation marks other than commas" (B-patterns), and all "breaks within the pentameter line dividing speeches by different characters" (C-patterns) (2). Oras's results for A-patterns, which are "formed by all the pauses indicated by internal punctuation" (3), show "the greatest continuity" in terms of authorial metrical development (13) and are ascertained by dividing the number of punctuation marks, or pauses, after each of the 9 positions in verse lines by the total number of pauses in a play or portion of a play. Oras provided raw figures for the plays he examined, as well as the percentages for each of the 9 pausal positions.

The striking similarities in patterns for same-author plays examined by Oras reveal that punctuation marks, be they authorial or compositorial (Oras examined the earliest editions available for each play), "keep within the rhythmical climate of the time" (3), and are thus useful for identifying playwrights' prosodic characteristics. It is unfortunate for our purpose that Oras recorded only C-figures for Brome, Ford, Middleton, and Webster's sole-authored plays (85-87), i. e. "breaks within the pentameter line dividing speeches by different characters" (3). Readers who consult Oras's data will find that breaks dividing speeches occur most frequently after syllable 6 in all of these playwrights' works, with the sole exception of Middleton's earlier play The Phoenix (1604). I reproduced Oras's method and recorded C-patterns for the portions assigned to a collaborator in The Noble Gentleman. Although this analysis is based on just 76 pauses in total, it is sufficient to identify a pattern:

Table 2. Ants Oras C-patterns in "Beaumont" Portions of The Noble Gentleman

\begin{tabular}{|l|r|r|r|r|r|r|r|r|r|r|r|}
\hline Title & $\begin{array}{l}\text { First } \\
\text { Half }\end{array}$ & Even & 1 & 2 & 3 & 4 & 5 & 6 & 7 & 8 & 9 \\
\hline $\begin{array}{l}\text { The Noble } \\
\begin{array}{l}\text { Gentleman } \\
\text { Collaborator }\end{array}\end{array}$ & 55.3 & 61.8 & 1.3 & 10.5 & 2.6 & 26.3 & 14.5 & 21.1 & 19.7 & 3.9 & - \\
\hline
\end{tabular}

The peak after the fourth syllable in The Noble Gentleman would be anomalous in the canons of Brome, Ford, Middleton, and Webster (Oras 1960: 85-87). We should also note that the pattern is quite unlike Beaumont's (Oras 1960, 85), whose sole-authored play The Knight of the Burning Pestle (1607) has a peak after syllable 6 and a figure of 14.5 for pauses in the first half of the line (i. e. syllables 1-4). In fact, the figure of 55.3 for these portions is higher than that 
found in the work of any candidate dramatist Oras surveyed. It is conceivable that these portions contain Fletcherian material revised by his posthumous collaborator, and Fletcher's figures for syllable 4 in his sole-authored plays are often higher than other candidate dramatists, according to Oras's data for C-patterns (1960: 84), which could affect results. However, this still does not account for the high figure found for pauses in the first half of the line, for none of Fletcher's sole-authored or co-authored works reach so high a percentage (Oras 1960: 84-85). Perhaps a theory of overwriting could account for the high percentage for this figure, as the presence of two hands in passages examined by Oras's method could produce results that are not representative of any single authorial candidate writing alone.

Fortunately, Vickers has recorded A-patterns in the poem A Funeral Elegy (1612), which is now universally attributed to Ford. This enables us to compare results for at least one of our candidate dramatists. As noted above, A-patterns give us a better insight into authorial metrical development than pauses dividing pentameter lines distributed between speakers, although the caveat about Fletcherian material above still stands, and we should acknowledge that $A$ Funeral Elegy was written much earlier than The Noble Gentleman and in a very different genre. Nevertheless, I reproduce Vickers's calculations (2002: 156-157) in comparison to my own calculations for the "non-Fletcherian" portions of The Noble Gentleman:

Table 3. Ants Oras A-patterns in "Beaumont" Portions of The Noble Gentleman and Ford's A Funeral Elegy

\begin{tabular}{|l|r|r|r|r|r|r|r|r|r|r|r|}
\hline Title & $\begin{array}{l}\text { First } \\
\text { Half }\end{array}$ & Even & 1 & 2 & 3 & 4 & 5 & 6 & 7 & 8 & 9 \\
\hline $\begin{array}{l}\text { A Funeral } \\
\text { Elegy }\end{array}$ & 41.4 & 68.5 & 2.0 & 7.7 & 2.0 & 23.4 & 15.5 & 31.9 & 11.3 & 5.6 & 0.8 \\
\hline $\begin{array}{l}\text { The Noble } \\
\text { Gentleman } \\
\text { Collaborator }\end{array}$ & 48.9 & 56.3 & 2.5 & 4.9 & 5.8 & 20.4 & 15.3 & 24.5 & 17.3 & 6.4 & 2.9 \\
\hline
\end{tabular}

My analysis of A-patterns is based on a total of 485 pauses, a far greater amount of data than C-patterns afford us. We can see that the overall pattern between Ford's poem and the "non-Fletcherian" portions of The Noble Gentleman is akin in almost every respect, with the exception of the third syllable, which is slightly elevated above the second in that play. The pause profile of these portions could therefore belong to Ford. 
As I alluded to earlier, Marina Tarlinskaja is a prosodist who examines every quantifiable aspect of authorial versification. She notes that "Unstressed grammatical monosyllables (the, to, and, is) tend to cling to the following or the preceding adjacent stressed lexical (content) word" (2014: 19). These clinging monosyllables are called "clitics", and "Potentially stressed clitics that precede their stressed 'host' and, as it were, lean forward" are known as "proclitics", while "those that follow a stressed word" and "lean backwards" are called "enclitics" (21). Tarlinskaja also examines feminine endings in English blank verse drama, as well as masculine endings (lines concluding in stressed syllables), and she has provided detailed analyses of the verse habits of writers like Fletcher, Ford, and Middleton during the course of her career.

I sent Marina Tarlinskaja the sample of text attributed to Fletcher's collaborator by Hoy. She noted that parts of the sample closely resemble Fletcher in their frequent use of enclitics - a strong Fletcherian marker - and the examples she discovered, such as "As every GOOD wife" and "To TAKE up wenches" do "look Fletcherian". Tarlinskaja concluded that "Fletcher is almost definitely there" in the portions assigned to a collaborator, but that these portions do not "catch all the features of Fletcher's style. If it is Fletcher, why not quite Fletcher? If it is not Fletcher, why so many Fletcher features?" A possible answer to Tarlinskaja's queries would be that Fletcher's hand can be traced in stretches of text that were overwritten by another author. Tarlinskaja was confident that in 4.3-5 "there are two authors" and that "the second author is not Middleton, for sure". While one of the authors "could be Fletcher", the verse style in these scenes overall "is not" that of "Webster" and more closely resembles "somebody like Ford". Tarlinskaja noted significant differences in the use of enclitics between different scenes and suggested that "the difference between the results" could be due to "different authorship". The "non-Fletcherian" author uses enclitics sparingly, and though "enclitics do exist" they are not employed "in the Fletcher way: not line-final, for example". The anonymous author's use of "feminine endings, mostly simple, fit into Ford's style", which is "more smooth", and there are "too many masculine endings" for Fletcher's usual style. There are "no heavy feminine endings at all: not a Fletcherian feature" in the passages confidently attributed to a different author. Tarlinskaja concluded that it is "very likely" that Ford's hand is present in these portions. ${ }^{6}$ Further work on the prosody and versification habits of plays by Ford, Webster, Middleton, Brome, Davenport, and Shirley in comparison to The Noble Gentleman would be a desideratum.

6 Email correspondence, 18 Dec. 2019. 
The remainder of this essay will focus on word "chunks", or phrasal repetitions in early modern drama. In Rizvi's database, a phrase four words in length will contain different types of $\mathrm{n}$-grams (contiguous word sequences): one tetragram (four-word phrase); two trigrams (three-word phrases); three bigrams; and four single words. These are what Rizvi would call "formal n-grams". The four-word phrase itself would also constitute what Rizvi calls a "maximal" $\mathrm{n}$-gram, in which case it would only be counted once. Rizvi notes on his website that, having tested 86 uncontested plays in his corpus, "unique n-grams are better than all n-grams" for correctly identifying authors, despite the fact that $\mathrm{n}$-grams unfiltered for rarity "provide a vastly greater amount of data". He also establishes that "unique" formal " 3 -grams" are the most reliable phrasal structures for attribution purposes and that his tests using these markers correctly identify all sole-authored Fletcher plays.

Users can download summary spreadsheets that rank play pairs in the electronic corpus according to all maximal n-gram matches, as well as unique maximal phrasal matches (i. e. occurring in only two plays in the corpus), whilst taking account of composite word counts. The rankings are determined by the weighted sum of indices, i. e. the number of matches shared between two plays is divided by the combined word count of that play pair. The power of Rizvi's database for distinguishing early modern dramatists is evident when he points out that, in the case of The Faithful Shepherdess (1608), only "two names appear at or near the top" of the summary spreadsheet: "John Fletcher and Francis Beaumont. If we had no external evidence of Fletcher's authorship, these n-gram counts would quickly identify the most likely candidates for us to investigate".

Unfortunately, the sample size of the "non-Fletcherian" portions of The Noble Gentleman was too small to provide reliable results for statistical formal $\mathrm{n}$-gram tests involving candidate authors' whole canons. The test involving unique trigrams assigned these portions to Webster while correctly identifying the author of every play tested, with the exception of Middleton's $A$ Yorkshire Tragedy (1605), which it also gave to Webster. These results might tell us more about the difficulties of examining small samples (Middleton's play is very short in comparison to other plays tested) than authorship. With the exception of Middleton's domestic tragedy, all sole-authored plays by Webster, Middleton, Ford, and Brome were correctly assigned by this test. The problem therefore seems to be the sample of text extracted from The Noble Gentleman and the possibility of passages containing islets of Fletcher, just as Hoy deemed the Fletcherian portions to be of mixed authorship. The scattered evidence for Fletcher's hand in the text is interesting in itself, in that it tells us something about the composition of the play and runs counter to the notion of early 
modern dramatists writing scene by scene, following their plot outlines in a largely linear arrangement. Shirley and Davenport's extant canons were too small to test according to this method, and of course the possibility remains that the collaborator could have been an unknown dramatist.

Given that much of the play seems to be of mixed authorship, we can consult Rizvi's spreadsheet for plays sharing maximal n-grams with The Noble Gentleman as a whole in order to determine the most likely collaborator. In doing so, we find that Ford's Love's Sacrifice (1633) is ranked fourth, higher than any text written by other feasible authorship candidates. Middleton's $A$ Trick to Catch the Old One (1605) is ranked eighth in Rizvi's database. Brome's The Queen and Concubine (1635) is ranked at 18, The Novella (1632) at 35, while his A Mad Couple Well Matched (1639) is at 37. Webster's top play is The White Devil (1612), ranked thirtieth. Shirley and Davenport's plays share few verbal affinities with The Noble Gentleman: Shirley's The Martyred Soldier is ranked 410 and Davenport's A New Trick to Cheat the Devil is at 497. On the basis of this single-play test, Ford is the most likely contributor to The Noble Gentleman.

Extremely rare phrases in Rizvi's corpus shared between The Noble Gentleman and Ford plays include the hexagram (six-word unit), "hath by me sent you this", and the bigram, "prithee servant", both unique to The Lover's Melancholy (1628); the distinctive trigrams, "shape and cutting" and "near the crown", which uniquely match Perkin Warbeck (1632); the tetragram, "with our great master", which provides a unique match with The Broken Heart (1629); the tetragrams, "a prince that thus", "sir 'tis well now", and "I shall observe them", all unique to Love's Sacrifice; the tetragram, "this I had prevented", unique to 'Tis Pity She's a Whore; the trigram, "your noble hand", which can be found in The Fancies Chaste and Noble (1636) and just one other play; and the tetragram, "kiss and kiss again", which co-occurs with The Queen (1627) and one other play performed between 1552 and 1657.

Below, I tabulate results for the top-ranked play written by each candidate author in comparison to The Noble Gentleman. I restrict my analysis of formal $\mathrm{n}$-grams to Rizvi's weighted figures for unique trigram matches because, as I mentioned earlier, Rizvi has shown on his website that these are the most reliable phrases for identifying authors, having correctly classified $98 \%$ of a corpus of uncontested plays. I also provide results for all unique maximal matches because, as MacDonald P. Jackson observes: "maximal counts of all unique matches, whatever their length" can "sometimes" perform "rather better and sometimes with about the same degree of success" as "unique formal 3-grams" (2019:212). Following Jackson's approach to Rizvi's data, the "weighted figures are multiplied by 10,000 so as to avoid the many zeros before decimal places" (206). 
Table 4. Top-ranked Plays by Candidate Dramatists in Pervez Rizvi's Database According to Unique Formal Trigrams and All Unique Maximal Matches

\begin{tabular}{|l|l|l|l|}
\hline Author & Play & $\begin{array}{l}\text { Unique } \\
\text { Formal } \\
\text { Trigrams }\end{array}$ & $\begin{array}{l}\text { All Unique } \\
\text { Maximal } \\
\text { Matches }\end{array}$ \\
\hline Ford & Love's Sacrifice & 2.96 & 3.46 \\
\hline Middleton & A Trick to Catch the Old One & 1.59 & 3.18 \\
\hline Webster & The White Devil & 1.80 & 2.47 \\
\hline Brome & The Queen and Concubine & 1.17 & 2.75 \\
\hline Davenport & A New Trick to Cheat the Devil & 0.25 & 0.25 \\
\hline Shirley & The Martyred Soldier & 0.00 & 0.55 \\
\hline
\end{tabular}

We can see that Ford's top play has stronger affinities according to both weighting measures than plays by other King's Men dramatists. We should also note that the phraseological evidence for Davenport and Shirley's participation in The Noble Gentleman is very weak on this basis. Thus, according to my analysis of unique formal trigrams and all unique maximal n-grams, Ford is more likely than the other candidate playwrights to have had a hand in The Noble Gentleman. It is striking that, to the best of my knowledge, no scholar has ever considered Ford's candidacy.

I now wish to explore the implications of an attribution to Ford in terms of his career as a professional dramatist. Firstly, we should acknowledge that the lack of personal names for characters in The Noble Gentleman, which Wiggins considers "a distinctively Middletonian trait" (2017: 166), is unlike Ford, whose names are often carefully sourced and of a literary nature. However, this might tell us more about the play's composition than its authorship: The Noble Gentleman is a posthumously collaborative play and Ford's contributions might have been concurrent with his work on The Fair Maid of the Inn; these plays were licensed just 12 days apart.

The Fair Maid of the Inn was licensed by Sir Henry Herbert as Fletcher's play on 22 January 1626. Hoy claimed that he could detect Fletcher's hand, albeit heavily overwritten by Ford, in 4.1 of this play, on the basis of certain lines having a "Fletcherian ring" (1960: 101). Vickers provides a detailed study of Philip Massinger, Webster, and Ford's hands in the play, but does not elaborate on Fletcher's purported contribution (2017: 288-308). In my investigation of Fletcher's proposed collaborations (Freebury-Jones, forthcoming), I discovered that Webster's The Devil's Law Case (1619) shares the most verbal affinities with this play in Rizvi's corpus, followed by Massinger's The Great 
Duke of Florence (1627) and The Bashful Lover (1636). The top-ranked Fletcher play is The Humorous Lieutenant (1619) at 11, but none of its unique maximal phrases co-occur with 4.1. Fletcher's entire sole-authored dramatic corpus shares just 4 unique matches with this scene, none of which are particularly remarkable when examined in context. On the other hand, the verbal texture is overwhelmingly Ford's: The Queen shares 4 unique phrases, as does 'Tis Pity She's a Whore; Love's Sacrifice shares 1 unique phrase; Perkin Warbeck shares 3; and The Lady's Trial (1638) shares 1 . Several of these parallels are highly individual combinations of thought and language. I have yet to encounter any compelling evidence for Fletcher's hand in this text, though it is conceivable that he was involved in plotting the play before his death. It is therefore possible that Ford was engaging with Fletcher's material on two collaborative plays at the same time.

We might ask ourselves: if Fletcher, who died in 1625, were unable to finish The Noble Gentleman, why would Ford be given the job rather than a more experienced King's Men dramatist? The answer could be circumstantial: Webster (Appius and Virginia), Massinger (A New Way to Pay Old Debts), and Middleton (a civic pageant written to commemorate King Charles I's entry into London) seem to have had projects in hand at this time, whereas Ford did not. It is also possibly significant that Ford was finally entrusted with sole authorship of The Queen during this period of his writing career. More research is required on this thorny attribution problem, given that there are limited prosodic and verbal data available, especially for dramatists with smaller canons, such as Davenport and Shirley. Having opened up new lines of enquiry, it is to be hoped that future investigators will conduct further work on the stylistic habits of dramatists writing for the King's Men during this period. Whereas this article has argued that Beaumont is not a feasible candidate for Fletcher's collaborator on The Noble Gentleman, it seems fair to say that, on the basis of linguistic preferences, prosody, verbal repetitions, and circumstantial evidence, Ford's candidacy is strong. 


\section{References}

Bowers, Fredson (ed.) 1976. The Dramatic Works in the Beaumont and Fletcher Canon: Volume Three, 10 vols. Cambridge: Cambridge University Press.

Butler, Martin. Brome, Richard (c. 1590-1652). In: Oxford Dictionary of National Biography. 4 Oct. 2007. https://doi.org/10.1093/ref:odnb/3503 (accessed June 4, 2020).

Byrne, Muriel St. Clare 1932. Bibliographic Clues in Collaborate Plays. In: Library, 4th series 13(1), 21-48. https://doi.org/10.1093/library/s4-XIII.1.21

Dyce, Alexander (ed.) 1846. The Works of Beaumont and Fletcher: Volume Ten, 11 vols. London: Bradbury and Evans.

Fleay, Frederick G. 1874. On Metrical Tests as Applied to Dramatic Poetry. Part II. Fletcher, Beaumont, Massinger. In: New Shakespere Society's Transactions 1, 51-72. https://catalog.hathitrust.org/Record/000054359

Freebury-Jones, Darren 2020. 'When a man hath a familiar style': An Introduction to Authorship Studies in Early Modern Drama and Literature. In: American Notes and Queries 33(2/3), 112-121. https://doi.org/10.1080/0895769X.2019.1677210

Freebury-Jones, Darren (forthcoming). Authorship Attributions in the Fletcher Canon.

Greg, Walter W. 1905. The Elder Brother. In: A. H. Bullen (ed.), The Works of Francis Beaumont and John Fletcher: Volume Two, 4 vols. London: G. Bell and Sons.

Hoy, Cyrus 1958. The Shares of Fletcher and his Collaborators in the Beaumont and Fletcher Canon. In: Studies in Bibliography 8, 85-106.

https://www.jstor.org/stable/40371173

Hoy, Cyrus 1960. The Shares of Fletcher and his Collaborators in the Beaumont and Fletcher Canon. In: Studies in Bibliography 13, 77-108. https://www.jstor.org/stable/40371277

Jackson, MacDonald P. 2019. Cyril Tourneur and The Honest Man's Fortune. In: Medieval and Renaissance Drama 32, 203-218.

Kathman, David. Davenport, Robert (fl. 1624-1640). In: Oxford Dictionary of National Biography. 23 Sep. 2004. https://doi.org/10.1093/ref:odnb/7204 (accessed June 4, 2020).

Kathman, David. Shirley, Henry (1591x7-1627). In: Oxford Dictionary of National Biography. 23 Sep. 2004. https://doi.org/10.1093/ref:odnb/25425 (accessed June 4, 2020). 
Lancashire, Ian 2010. Forgetful Muses: Reading the Author in the Text. London: University of Toronto Press.

Oliphant, Ernest H. C. 1927. The Plays of Beaumont and Fletcher: An Attempt to Determine Their Respective Shares and the Shares of Others. New Haven: Yale University Press.

Oras, Ants 1953. "Extra Monosyllables" in Henry VIII and the Problem of Authorship. In: Journal of English and Germanic Philology 52(2), 198-213. https://www.jstor.org/stable/27713526

Oras, Ants 1960. Pause Patterns in Elizabethan and Jacobean Drama: An Experiment in Prosody. Gainesville, Florida: University of Florida Press.

Rizvi, Pervez. Collocations and N-grams. Initial launch Oct. 2017. http://shakespearestext.com/can/ (accessed Nov. 11, 2019).

Sykes, Henry Dugdale 1924. Sidelights on Elizabethan Drama. New York: Routledge.

Tarlinskaja, Marina 2014. Shakespeare and the Versification of Elizabethan Drama 1561-1642. Farnham: Ashgate.

Thorndike, Ashley H. 1901. The Influence of Beaumont and Fletcher on Shakespeare. Worcester, MA: Wood.

Vickers, Brian 2002. "Counterfeiting” Shakespeare: Evidence, Authorship and John Ford's Funerall Elegye. Cambridge: Cambridge University Press.

Vickers, Brian 2014. The Two Authors of Edward III. In: Holland, Peter (ed.), Shakespeare's Collaborative Work (Shakespeare Survey 67). Cambridge: Cambridge University Press, 102-118. https://doi.org/10.1017/SSO9781107775572.008

Vickers, Brian (ed.) 2017. The Collected Works of John Ford: Volume Two, 5 vols. Oxford: Oxford University Press.

Wiggins, Martin 2012-. British Drama 1533-1642: A Catalogue. Oxford: Oxford University Press.

Wilson Jr, Robert F. 1968. Francis Beaumont and the 'Noble Gentleman'. In: English Studies. New Series 49, 523-529. 